\title{
PERAN PEMERINTAH DAERAH DALAM PENYULUHAN PEMELIHARAAN AYAM BROILER DI DESA TANRARA KECAMATAN BONTONOMPO SELATAN KABUPATEN GOWA
}

\author{
Rini Pebrianti1'Lukman Hakim² Syamsir Rahim² \\ ${ }^{1}$ Program Studi Ilmu Pemerintahan Fakultas Ilmu Sosial dan Ilmu Politik \\ Universitas Muhammadiyah Makassar \\ Jl. Sultan Alauddin No. 259 Makassar 90221 \\ Telp. 0411-866972 ext.107.Fax.0411-8655888 \\ rinipebrianti@yahoo.co.id \\ ${ }^{2}$ Program Studi Ilmu Administrasi Negara Fakultas Ilmu Sosial dan Ilmu Politik \\ Universitas Muhammadiyah Makassar \\ Jl. Sultan Alauddin No. 259 Makassar 90221 \\ Telp. 0411-866972 ext.107.Fax.0411-8655888 \\ Lukmanhakim20@yahoo.com, syamsirr@gmail.com
}

\section{ABSTRACT}

The aim of this study was to obtain a picture of how the role of the local government in the counseling of medical care of broiler chickens in the village of Tanrara, South Bontonompo District, Regency of Gowa and analysis counseling medical care of broiler chicken farms. Type of research used is descriptive qualitative, Data is collected using a technical field research, library research and data searches on line. The data were then analyzed qualitatively to explain or describe the data examined of the field, both primary data obtained from interviews, as well as from secondary data. The results of this study indicate that the Agency's role in the maintenance of broiler chickens counseling is to provide education to farmers (educational roles), provide assistance to farmers, as a facilitator for the farmers, as well as help increase the productivity of resources and ranchers. Counseling of medical care of broiler chickens may improve outcomes farm broiler chickens caused by could encourage increased production and productivity of poultry broiler, encourage availability of broiler chickens is always stable on the market, local goverment encourage increased incomes and welfare of broiler breeders as well as help the marketing of chicken broiler widespread.

Keywords: local government, counseling, livestock

\section{ABSTRAK}

Penelitian ini bertujuan untuk memperoleh gambaran tentang bagaimana peran Dinas Perikanan, Kelautan, dan Peternakan dalam penyuluhan pemeliharaan ayam broiler di Desa Tanrara Kecamatan Bontonompo Selatan Kabupaten Gowa serta ananlisis mengenai penyuluhan pemeliharaan ayam broiler. Tipe penelitian yang dipergunakan adalah diskriptif kualitatif. Pengumpulan data dilakukan menggunakan teknis field research library research dan penelusuran data on line. Data yang diperoleh selanjutnya dianalisis secara kualitatif dengan menjelaskan atau menggambarkan data yang diteliti dari lapangan, baik data primer yang diperoleh dari hasil wawancara, maupun dari data sekunder. Hasil penelitian ini menunjukkan bahwa peran Dinas dalam penyuluhan pemeliharaan ayam broiler adalah memberikan pendidikan kepada peternak, memberikan pendampingan teknis kepada peternak, sebagai fasilitator bagi para peternak, serta membantu meningkatkan sumber daya dan produktivitas peternak. Penyuluhan pemeliharaan ayam broiler dapat meningkatkan hasil peternakan ayam broiler disebabkan oleh penyuluhan mampu mendorong meningkatnya produksi dan produktivitas peternakan ayam broiler, mendorong ketersedian ayam broiler selalu stabil di pasar. Pemerintah daerah mendorong meningkatnya pendapatan dan kesejahteraan peternak ayam broiler serta membantu pemasaran ayam broiler yang semakin meluas.

Kata kunci : pemerintah daerah, penyuluhan, peternakan 


\section{A. PENDAHULUAN}

Industri peternakan khususnya ayam pedaging (ayam broiler) telah tumbuh menjadi penopang ekonomi nasional dengan sejumlah keterkaitan pada beberapa industri lainnya.Selain menjadi pendorong ekonomi khususnya di pedesaan, industri ini juga banyak menberikan kesempatan kerja bagi para peternak di beberapa wilayah.Konsumsi masyarakat yang meningkat disertai menguatnya daya beli terhadap daging dan telur sangat membantu industri hulu dan hilir peternakan. Hambatan yang dihadapi para peternak ayam broiler adalah kurangnya kesiapan mereka dalam menanggulangi wabah penyakit yang dapat menyebabkan kematian pada ayam broiler. Hal ini dapat terjadi jika masyarakat masih memiliki pengetahuan yang minim tentang penanggulangan penyakit tersebut.

Hambatan lain yang dihadapi oleh para peternak adalah fluktuasi harga ayam broiler. Untuk mengatasi hambatan-hambatan tersebut, Penyuluhan peternakan berperan penting bagi pembangunan peternakan, sebab penyuluhan merupakan salah satu upaya pemberdayaan peternak dan pelaku usaha peternakan lain untuk meningkatkan produktivitas, pendapatan dan kesejahteraannya. Melalui kegiatan penyuluhan, para peternak ditingkatkan kemampuannya agar dapat mengelola usaha taninya dengan produktif, efisien dan menguntungkan, sehingga peternak dan keluarganya dapat meningkatkan kesejahteraanya.

Dari uraian diatas, jelas bahwa untuk menyukseskan pembangunan di bidang peternakan tidak terlepas dari peran seorang penyuluh sebagai fasilitator yang dapat memberikan kontribusi bagi para peternak dalam hal menyelesaikan permasalahan di bidang peternakan. Dengan demikian, tujuan program penyuluhan adalah untuk mengubah peternak yang kemudian dapat membuat keputusan untuk mengubah usaha taninya. Perubahan inilah yang menjadi tujuan terpenting pendidikan penyuluhan.

Peternak adalah pelaku utama dalam kegiatan produksi peternakan serta bagian dari masyarakat Indonesia yang perlu ditingkatkan kesejahteraan dan kecerdasannya, salah satu upaya peningkatan kecerdasan tersebut dilaksanakan melalui kegiatan penyuluhan.

Di Desa Tanrara Kecamatan Bontonompo Selatan Kabupaten Gowa, kebanyakan peternak ayam broiler masih mengalami banyak hambatan dalam meningkatkan hasil ternaknya. Hal ini dialami terutama oleh para peternak ayam mandiri. Peranan Penyuluh Peternakan di desa ini sangat dibutuhkan untuk pengembangan hasil ternaknya.

Sektor peternakan merupakan salah satu sumber perekonomian utama di Kecamatan Bontonompo. Oleh karena itu keberhasilan pembangunan peternakan sangat menentukan peningkatan aktivitas ekonomi dan kesejahteraan masyarakat. Hal ini hanya dapat dicapai apabila pelaku utama dan pelaku usaha peternakan memiliki kemampuan manajerial, kewirausahaan, dan organisasi bisnis yang handal sehingga pelaku peternakan mampu membangun usaha dari hulu sampai dengan hilir yang berdaya saing tinggi. Untuk itulah dibutuhkan dukungan dari sistem penyuluhan yang handal dalam meningkatkan hasil usaha mereka.

Dari uraian latar belakang diatas penulis tertarik melakukan penelitian mengenai "Peran Pemerintah Daerah Dalam Penyuluhan Pemeliharaan Ayam Broiler di Desa Tanrara Kecamatan Bontonompo Selatan Kabupaten Gowa".

\section{A. KONSEP PENYULUHAN PETERNAKAN}

Pada hakekatnya tugas dan fungsi dinas perikanan, kelautan, dan peternakan sebagai perpanjangan tangan dari pemerintah dalam memberikan kemudahan kepada para petenak ayam broiler untuk pengaksesan sumber pembiayaan, permodalan, ilmu pengetahuan dan teknologi, informasi pelayanan peternakan, pelayanan kesehatan hewan, bantuan teknik, penghindaran pengenaan biaya yang menimbulkan ekonomi biaya tinggi, pembinaan kemitraan dalam meningkatkan sinergi antar pelaku usaha, penciptaan iklim usaha yang kondusif dan/atau meningkatan kewirausahaan pengutamaan pemanfaatan sumber daya peternakan dan kesehatan hewan dalam negeri, 
pemfasilitasan pengembangan pemfasilitasan pemasaran dan perlindungan harga dan produk hewan dari luar negeri.

Pengertian peran merupakan pengertian yang dikembangkan oleh paham strukturalis di mana lebih berkaitan antara peran-peran sebagai unit kultural yang mengacu kepada hak dan kewajiban yang secara normatif telah dicanangkan oleh sistem budaya. Sedangkan pengertian peran dalam kelompok dua adalah paham interaksionis, karena lebih memperlihatkan konotasi aktif dinamis dari fenomena peran.Seseorang dikatakan menjalankan peran manakala ia menjalankan hak dan kewajiban yang merupakan bagian tidak terpisah dari status yang disandangnya.

Secara harfiah bahasa "Penyuluhan" berasal dari kata "suluh" yang berarti "obor" atau "pelita" ataberi terang.Berdasarkan Undangundang Nomor 16 Tahun 2006 Tentang Sistem Penyuluhan Pertanian, Perikanan dan Kehutanan; penyuluhan didefinisikan sebagai proses pembelajaran bagi pelaku utama serta pelaku usaha agar mereka mau dan mampu menolong dan mengorganisasikan dirinya dalam mengakses informasi pasar, teknologi, permodalan, dan sumberdaya lainnya, sebagai upaya untuk meningkatkan produktivitas, efisiensi usaha, pendapatan, dan kesejahteraan, serta meningkatkan kesadaran dalam pelestarian fungsi lingkungan hidup.

Alim (2010:6) menuturkan bahwa Terminologi penyuluhan pertama kali dikenal pada pertengahan abad 19 oleh universitas Oxford dan Cambridge pada sekitar tahun 1850. Di Indonesia, kata "penyuluhan" diyakini mengacu dari istilah bahasa Belanda voorlichting yaitu memberikan penerangan kepada orang agar dapat menemukan jalan. Atas dasar pengertian tersebut maka penyuluhan dapat diartikan sebagai keterlibatan seseorang untuk melakukan komunikasi informasi secara sadar dengan tujuan membantu sesamanya memberikan pendapat sehingga bisa membuat keputusan yang benar.

Terkait dengan hal tersebut, di dalam perjalanannya, kegiatan penyuluhan dapat diartikan dengan berbagai pemahaman (Alim, 2010) seperti : Penyebar-luasan (informasi), Penerangan/penjelasan, Pendidikan non-formal (luar-sekolah), Perubahan perilaku, Rekayasa sosial, Pemasaran inovasi (teknis dan sosial), Perubahan sosial (perilaku individu, nilainilai, hubungan antar individu, kelembagaan, dll), Pemberdayaan masyarakat (community empowerment), Penguatan komunitas (community strengthening).

\section{B. PENYULUHAN PETERNAKAN}

Sumberdaya manusia merupakan salah satu faktor kunci dalam reformasi ekonomi, yaitu menciptakan sumberdaya manusia yang berkualitas dan memiliki keterampilan serta berdaya saing tinggi dalam menghadapi persaingan global yang selama ini terabaikan. Dalam kaitan itu ada dua hal yang penting yang menyangkut kondisi sumberdaya manusia dalam bidang peternakan di daerah yang perlu mendapatkan perhatian yaitu sumberdaya petugas dan sumberdaya peternak. Banyak pihak menilai bahwa penyuluhan peternakan mempunyai andil yang sangat besar dalam keberhasilan pembangunan peternakan di Indonesia.

Penyuluhan pada dasarnya adalah pendidikan dimana target/sasarannya yaitu para petani/peternak harus mengalami perubah an perilaku, dari mulai aspek yang bersifat kognitif, afektif dan akhirnya psikomotorik (Alim, 2010). Oleh sebab itu tugas utama seorang penyuluh peternakan adalah membantu peternak dalam mengambil keputusan.

\section{FALSAFAH DAN PRINSIP PENYULUHAN PETERNAKAN}

Falsafah adalah landasan pemikiran/pandangan hidup yang bersumber kepada kebijkan moral tentang segala sesuatu yang akan dan harus diterapkan di dalam praktek. Sedangkan prinsip adalah suatu pernyataan tentang kebijaksanaan yang dijadikan pedoman dalam pengambilan keputusan dan melaksanakan kegiatan secara konsisten. 
Adapun falsafah penyuluhan adalah (Suharyanto, 2008) Penyuluhan sebagai proses pendidikan, yaitu dalam proses pendidikan menganut falsafah pendidikan yang dikemukakan oleh $\mathrm{Ki}$ Hajar Dewantoro yang berbunyi: ing ngarso sung tulodo, mampu memberikan contoh atau teladan bagi masyarakat sasarannya; Ing madyo mangun karso, mampu menumbuhkan inisiatif dan mendorong kreativitas, serta semangat dan motivasi untuk selalu belajar dan mencoba;

Tut Wuri Handayani, mau menghargai dan mengikuti keinginan keinginan serta upaya yang dil akukan masyarakat petaninya, sepanjang tidak menyimpang /meninggalkan acuan yang ada, demi tercapainya tujuan perbaikan kesejahteraan hidupnya.

Penyuluhan sebagai proses demokrasi, yaitu berperan setara antara peternak dan penyuluh penyuluhan sebagai proses yang terus menerus/berkesinambungan, yaitu terus menerus saling terkait dan tiada akhir serta terkait dengan perkembangan teknologi dan ilmu pengetahuan

Adapun prinsip-prinsip dalam penyuluhan adalah: (1) Prinsip penyuluhan peternakan adalah pedoman atau pegangan kerja yang lebih konkrit dan operasional dalam menyelenggarakan kegiatan-kegiatan penyuluhan peternakan, yang disepakati pihak-pihak yang terkait dalam kegiatan penyuluhan. (2) Penyuluhan peternakan seyogianya diselenggarakan menurut keadaan-keadaan yang nyata. (3) Penyuluhan peternakan seharusnya ditujukan kepada kepentingan dan kebutuhan sasaran. (4) Penyuluhan peternakan ditujukan kepada seluruh anggota keluarga. (5) Penyuluhan peternakan adalah pendidikan untuk demokrasi. Harus ada kerja sama yang erat antara penyuluhan, penelitian, dan pendidikan.

\section{F. KINERJA PENYULUH PETERNAKAN}

Disahkannya Undang-undang Nomor 16 Tahun 2006 Tentang Sistem Penyuluhan Pertanian, Perikanan dan Kehutanan di sisi lain memberikan kepastian hukum tentang peran penyuluhan di berbagai bidang (pertanian/peternakan, perikanan dan kehutanan), tetapi di sisi lain juga menyisakan permasalahan mendasar seperti penyiapan sumberdaya manusia penyuluh. Sumberdaya Manusia yang handal akan mampu meningkatkan kinerja pelayanan kepada masyarakat.

Ada empat kualifikasi yang harus dimiliki setiap penyuluh peranian/peternakan untuk meningkatkan kinerjanya (Ali, 2013) yaitu kemampuan untuk berkomunikasi yaitu kemampuan dan keterampilan penyuluh untuk berempati dan berinteraksi dengan masyarakat sasarannya.

\section{G. METODE PENYULUHAN}

Adapun berbagai macam metode penyuluhan pertanian menurut Alim (2010: 31) antara lain : (1) Berdasarkan teknik komunikasi metode penyuluhan dapat dibedakan antara yang langsung muka ke muka (face to face communication) dan yang tidak langsung (indirect communication). Metode yang langsung digunakan pada waktu penyuluhan pertanian/peternakan berhadapan muka dengan sasarannya sehingga memperoleh respon dari sasaran nya dalam waktu yang relatif singkat. Misalnya pembicaraan di balai desa, di sawah, dalam kursus, demonstrasi dan sebagainya. Metode yang langsung ini dianggap lebih efektif, meyakinkan dan mengakrabkan hubungan antara penyuluh dan sasaran serta cepatnya respon atau umpan balik dari sasaran. Namun, dalam kondisi terbatasnya personalia, kurangnya saranan transportsasi, terbatasnya biaya dan waktu maka metode ini kurang efisien.

Metode yang tidak langsung digunakan oleh penyuluhan pertanian/peternakan yang tidak langsung berhadapan dengan sasaran, tetapi menyampaikan pesannya melalui perantara (medium atau media). Contohnya adalah media cetak (majalah, koran), media elektronik (radio, televisi), media pertunjukan atau sandiwara, pameran dan lain-lain. Metode tidak langsung ini dapat menolong banyak sekali apabila metode langsung tidak memungkinkan digunakan. Terutama 
dalam upaya menarik perhatian dan menggugah hati sasaran. Siaran lewat radio dan televisi dapat menarik banyak perhatian, bila ditangani secara tepat. Namun metode penyuluhan tak langsung tidak memungkinkan penyuluh mendapatkan respon dari sasaran dalam waktu relatif singkat.

(2) Metode Berdasarkan Jumlah Sasaran dan Proses Adopsi maka penyuluhan dibedakan menjadi hubungan perseorangan, hubungan kelompok dan hubungan masal. Metode dengan hubungan perseorangan digunakan penyuluhan pertanian/peternakan untuk berhubungan langsung maupun tidak langsung dengan masing-masing orangnya. Misalnya kunjungan ke rumah, ke sawah, ke kantor, pengiriman surat kepada perseorangan dan hubungan telepon.

Metode dengan hubungan kelompok digunakan oleh penyuluhan pertanian/peternakan untuk menyampaikan pesan kepada kelompok. Metode ini sesuai dengan keadaan dan norma sosial dari masyarakat pedesaan Indonesia, seperti hidup berkelompok, bergotong-royong dan berjiwa musyawarah. Contohnya adalah pertemuan, demontrasi, karya wisata, pameran, perlombaan, kursus, diskusi kelompok dan lain -lain.

Metode dengan hubungan masal digunakan oleh penyuluhan pertanian dan peternakan untuk menyampaikan pesan langsung atau tidak langsung kepada banyak orang sekaligus pada waktu yang hampir bersama an. Contohnya adalah pidato dalam pertemuan besar, siaran pedesaan lewat radio dan televisi, pertunjukan wayang atau dagelan, penyebaran bahan cetakan, penempelan poster, pembentangan spanduk dan lain-lain. Metode ini digunakan untuk menarik minat dan perhatian masyarakat akan sesuatu rekomendasi usaha tani-ternak.

(3) Metode Berdasarkan Indera Penerima pada sasaran metode penyuluhan dapat digolongkan menjadi metode yang dapat dilihat, metode yang dapat didengar serta metode yang dapat dilihat dan didengar. Dalam metode yang dapat dilihat, pesan penyuluhannya diterima oleh sasaran melalui indera penglihatan. Contohnya adalah metode publikasi barang cetakan, gambar, poster, leaflet dan lain-lain. Dalam metode yang dapat didengar pesan penyuluhannya diterima oleh sasaran melalui indera pendengaran. Contohnya siaran lewat radio dan tape recorder, hubungan melalui telepon, pidato ceramah dan lain -lain. Sedangkan metode yang dapat dilihat dan didengar pesan penyuluhannya diterima oleh sasaran melalui indera penglihatan dan pendengaran sekaligus. Contohnya adalah metode pertunjukan film bersuara, siaran lewat televisi, wayang, kursus berupa pelajaran dikelas dan prakteknya, karya wisata, pameran dengan penjelasan lisan.

Metode penyuluhan yang Efektif dan Efisien Suatu metode disebut efektif apabila dengan metode yang digunakan dalam suatu kegiatan penyuluhan, tuj uan yang diinginkan tercapai (Martanegara, 1993). Unsur -unsur dari keefektifan metode penyuluhan adalah (Martanegara, 1993): Tingkat kemampuan penyuluh, yaitu pengetahuan dan keterampilan penyuluh dalam memberikan informasi penyuluhan.

Keadaan alat bantu penyuluhan yaitu ketersediaan alat bantu pada saat penyuluhan. Kesesuaian waktu dan tempat penyuluhan yaitu kesesuaian dan ketepatan waktu pertemuan dan tempat pelaksanaannya.

Materi penyuluhan, yaitu ketepatan dan kesesuaian materi penyuluhan dengan masalah yang dihadapi. Kondisi dan tingkat adopsi peternak. Kesesuaian dengan tujuan yang ingin dicapai yaitu kejelasan dan kesesuai tujuan penyuluhan dengan kepentingan-kepentingan sasaran.

Sedangkan efisien berarti hemat, dalam arti menggunakan semua sumber daya (tenaga, waktu, pikiran dan biaya) sekecil mungkin untuk mendapatkan hasil sebesar-besar (tujuan penyuluhan tercapai).

$$
\text { Undang Undang Republik }
$$

Indonesia, Nomor 16 Tahun 2006, menyatakan bahwa penyuluhan adalah proses pembelajaran bagi pelaku utama serta pelaku usaha agar mereka mau dan mampu menolong dan mengorganisasikan 
dirinya dalam mengakses informasi pasar, teknologi, permodalan, dan sumberdaya lainnya, sebagai upaya untuk meningkatkan produktivitas, efisiensi usaha, pendapatan, dan kesejahteraannya, serta meningkatkan kesadaran dalam pelestarian fungsi lingkungan hidup. Sistem penyuluhan adalah seluruh rangkaian pengembangan kemampuan, pengetahuan, keterampilan, serta sikap pelaku utama dan pelaku usaha melalui penyuluhan.

Seiring waktu berjalan ayam broiler semakin berkembang setiap tahunnya, hal tersebut diiringi dengan semakin banyaknya produsen input seperti pakan ternak, DOC, serta input lainnya yang menawarkan produk. Undang-Undang No. 18 Tahun 2009 Tentang Peternakan dan Kesehatan Hewan menyatakan pemberdayaan peternak, usaha di bidang peternakan, dan usaha di bidang kesehatan hewan dilakukan dengan memberikan kemudahan bagi kemajuan usaha di bidang peternakan dan kesehatan hewan serta peningkatan daya saing. Kemudahan yang diberikan oleh pemerintah tersebut meliputi: a) pengaksesan sumber pembiayaan, permodalan, ilmu pengetahuan dan teknologi, serta informasi; b) pelayanan peternakan, pelayanan kesehatan hewan, dan bantuan teknik; c) penghindaran pengenaan biaya yang menimbulkan ekonomi biaya tinggi; d) pembinaan kemitraan dalam meningkatkan sinergi antarpelaku usaha; e) penciptaan iklim usaha yang kondusif dan/atau meningkatan kewirausahaan; f) pengutamaan pemanfaatan sumber daya peternakan dan kesehatan hewan dalam negeri; g) pemfasilitasan terbentuknya kawasan pengembangan usaha peternakan; h) pemfasilitasan pelaksanaan promosi dan pemasaran; dan i) perlindungan harga dan produk hewan dari luar negeri.

Keterlibatan pemerintah dalam penanganan produksi ayam broiler ini diharapkan akan mendukung semakin membaiknya kondisi peternakan ayam broiler di Indonesia karena mendapatkan penyuluhan langsung tentang usaha peternakan ayam broiler. Dalam hal ini, penyuluhan diakukan oleh dinas yang terkait yaitu para Petugas Penyuluh Lapangan (PPL) dari Dinas Perikanan, Kelautan, dan Peternakan Kabupaten Gowa yang terjun langsung memberikan penyuluhan kepada para peternak ayam broiler. Pendampingan para penyuluh ini sangat membantu peternak ayam tersebut. Usaha peternakan dapat digolongkan menjadi beberapa bagian., yaitu Peternakan Rakyat, Pengusaha Kecil Peternakan dan Pengusaha Peternakan. Peternakan Rakyat adalah peternak yang mengusahakan budidaya ayam broiler dengan kapasitas maksimal sebesar 15.000 ekor per periode. Peternakan rakyat mempunyai beberapa karakter yaitu modal terbatas, adanya masa istrahat kandang, kandang dibangun dengan sederhana, tenaga kerja biasanya dari rumah tangga.

Pengusaha kecil peternakan adalah peternak yang membudidayakan ayam broiler dengan kapasitas maksimal sebesar 65.000 ekor per periode, peternakan ini sudah mulai baik dibandingkan dengan peternakan rakyat dibidang manajemen, tenaga kerja yang sudah memiliki pengalaman dan biasanya sudah memiliki legalitas hukum berupa perseorangan.

\section{G. METODE PENELITIAN}

Penelitian ini dilaksanakan di Desa Tanrara Kecamatan Bontonompo Selatan Kabupaten Gowa.Dalam penelitian ini menggunakan metode penelitian kualitatif. Tipe penelitian yang digunakan penulis adalah penelitian tipe deskriptif Kualitatif.

Sumber data dari penelitian ini didapatkan dari sumber data primer adalah data yang diperoleh penulis secara langsung dari informan kunci berupa informasi dan persepsi serta tanggapan yang berkaitan dengan penelitian ini, yaitu dengan melakukan observasi dan wawancara (interview) dengan beberapa peternak ayam broiler yang ada di Desa Tanrara Kecamatan Bontonompo Selatan Kabupaten Gowa serta petugas penyuluhan lapangan (PPL). Data sekunder adalah data 
yang diperoleh penulisdari buku-buku, beberapa dokumen berupa laporan-laporan tertulis dan peraturan-peraturan yang ada hubungannya denganinformasi yang dibutuhkan penulis yaitu mengenai Peran Dinas Peternakan dan Perikanan Dalam Penyuluhan Pemeliharaan Ayam Broiler di Desa Tanrara Kecamatan Bontonompo Selatan Kabupaten gowa Gowa.

Teknik pengumpulan data yang digunakan dalam penelitian oleh penulis yaitu :Observasi, wawancara,dan dokumen. Teknik analisis data yang di gunakan adalah analisis kualitatif dilakukan dengan menggambarkan data-data tentang Peran Dinas Peternakan dan Perikanan Dalam Penyuluhan Pemeliharaan Ayam Broiler di Desa Tanrara Kecamatan Bontonompo Selatan Kabupaten Gowa.

Setelah menganalisis data, peneliti harus memastikan apakah interpretasi dan temuan penelitian akurat. Validasi temuan peneliti menentukan keakuratan dan kredibilitas temuan melalui beberapa strategi, antara lain member checking, triangulasi dan auditing (Sugiyono, $2012: 42$ ).

\section{H. HASIL DAN PEMBAHASAN}

Sebagai produk peternakan yang selalu dibutuhkan masyarakat, peternakan ayam broiler di Kabupaten Gowa memiliki potensi yang cukup besar sebagai salah satu komoditi yang dapat dikembangkan oleh masyarakat Gowa utamanya oleh masyarakat Desa Tanrara Kecamatan Bontonompo Selatan Kabupaten Gowa. Oleh karena itu, peternakan ayam broiler perlu mendapatkan perhatian dari pemerintah dalam rangka peningkatan dari segi kuantitas maupun kualitasnya, agar pemasarannya dapat berkembang dapat memenuhi kebutuhan yang semakin hari semakin meningkat dan meningkatkan taraf hidup para peternak. Dalam hal ini, yang berperan dalam pengembangan peternakan ayam broiler adalah penyuluhan peternakan yang merupakan salah satu program peternakan dari Dinas Perikanan, Kelautan, dan Peternakan Kabupaten Gowa. Adapun Peran
Dinas Perikanan, Kelautan, dan Peternakan Dalam Penyuluhan Pemeliharaan Ayam Broiler di Desa Tanrara Kecamatan Bontonompo Selatan Kabupaten Gowa. Adalah sebagai berikut:

\section{Memberikan Pendidikan Kepada Peternak (Educational Roles)}

Undang Undang Republik
Indonesia, Nomor 16 Tahun 2006,
menyatakan bahwa penyuluhan adalah
proses pembelajaran bagi pelaku utama
serta pelaku usaha agar mereka mau dan
mampu menolong dan mengorganisasikan
dirinya dalam mengakses informasi pasar,
teknologi, permodalan, dan sumberdaya
lainnya, sebagai upaya untuk meningkatkan
produktivitas, efisiensi usaha, pendapatan,
dan kesejahteraannya, serta meningkatkan
kesadaran dalam pelestarian fungsi
lingkungan hidup. Sebagaimana
diungkapkan oleh Penyuluh Pertanian
Lapangan (PPL) Dinas Peternakan Gowa
sebagai berikut:
“...Fungsi dari kegiatan penyuluhan
yaitu memeberikan pegetahuan
kepada para peternak dalam proses
pemeliharaan ayam broiler, baik
dari segi kesehatan, pertumbuhan
ayam broiler sampai mendapatkan
keuntungan yang signifikan...”
(Wawancara, SU).

Bentuk pendidikan yang dilaksanakan oleh Dinas Perikanan, Kelautan, dan Peternakan Kabupaten Gowa bagi para peternak ayam broiler di Desa Tanrara yaitu melalui penyuluhan pemeliharaan ayam broiler. Dalam melakukan penyuluhan tersebut, terdapat metode yang digunakan oleh para penyuluh peternakan dari Dinas Perikanan, Kelautan, dan Peternakan Kabupaten Gowa dalam melakukan penyuluhan kepada peternak ayam broiler.

Metode yang digunakan oleh para penyuluh peternakan dari Dinas Perikanan, Kelautan, dan Peternakan Kabupaten Gowa saat penyuluhan pemeliharaan ayam 
broiler kepada para peternak adalah menggunakan metode tatap langsung. Dalam metode ini, Para penyuluh dari Dinas Perikanan, Kelautan, dan Peternakan Kabupaten Gowa menjabarkan tentang pemeliharaan ayam broiler kepada peternak dengan cara sosialisasi secara massal dimana para peternak ayam broiler diundang di suatu tempat kemudian diberikan penyuluhan..

Dalam memberikan penyuluhan, para penyuluh dari Dinas Perikanan, Kelautan, dan Peternakan Kabupaten Gowa menggunakan metode tatap langsung.Metode ini sangat tepat digunakan pada penyuluhan peternakan pemeliharaan ayam broiler di Desa Tanrara.

\section{Memberikan Pendampingan Teknis Kepada Peternak}

Pendampingan teknis adalah kegiatan pembangunan kemampuan bakat yang merupakan aktivitas penyuluhan yang dilakukan secara terus menerus pada kegiatan pembangunan kemampuan bakat untuk meningkatkan keberhasilan dan keberlajutan pembangunan bakat serta keberdayaan dan kesejahteraan masyarakat. Pendampingan dan penyuluhan seringkali dipahami sebagai kegiatan yang berbeda dan terpisah, tetapi sesungguhnya pendampingan dan penyuluhan memiliki kesamaan tujuan dan merupakan kegiatan yang sejalan. Oleh karena itu, Dinas Perikanan, Kelautan, dan Peternakan Kabupaten Gowa melalui para penyuluh peternakan memberikan bimbingan teknis kepada masyarakat sebagaimana dinyatakan oleh wawancara berikut:

“...untuk membuat para peternak lebih paham mengenai pengelolaan pemeliharaan ayam broiler yang baik, kegiatan penyuluhan lebih sering kami lakukan. Dari dinas peternakan dilaksanakan dua kali dalam sebulan dan petugas penyuluhan setiap hari mendatangi kandang pemeliharaan ayam broiler untuk sosialisasi mengenai pemeliharaan ayam broiler..." (Wawancara, KK)

Selain memberikan pendidikan kepada para peternak ayam broiler di Desa
Tanrara melalui penyuluhan secara berkala yang dilaksanakan dua kali dalam sebulan, Dinas Perikanan, Kelautan, dan Peternakan Kabupaten Gowa juga memberikan pendampingan secara langsung kepada para peternak. Petugas Penyuluh Pertanian Lapangan (PPL) dari Dinas Perikanan, Kelautan, dan Peternakan Kabupaten Gowa setiap hari mendatangi kandang pemeliharaan ayam broiler di desa Tanrara kemudian melakukan sosialisasi kepada masyarakat secara langsung sebagaimana diungkapakan oleh Petugas Penyuluh Pertanian Lapangan (PPL) dari Dinas Perikanan, Kelautan, dan Peternakan Kabupaten Gowa.

Proses pendampingan dilakukan secara di mulai dari pemilihan bibit, dimana peternak dibekali mengenai pemilihan bibit ayam yang berkualitas, pemeliharaan ayam broiler yang baik, bimbingan dalam pemberian pakan dan minum yang berkualitas, tata cara pemeliharaan kandang serta memberikan bimbingan kepada peternak pada saat vaksinasi dan pemberian obat kepada ayam broiler sehingga penyakit yang mungkindapat mejangkiti ayam broiler dapat dicegah. Pendampingan ini mendapatkan respon yang positif dari para peternak sebagaiman dipaparkan oleh Petugas Penyuluh Pertanian Lapangan (PPL) dari Dinas Perikanan, Kelautan, dan Peternakan Kabupaten Gowa.

\section{Sebagai Fasilitator bagi Para Peternak}

Selain memberikan pendidikan dan bimbingan berkelanjutan bagi para peternak ayam broiler di Desa Tanrara, Dinas Perikanan, Kelautan, dan Peternakan Kabupaten Gowa juga berperan sebagai fasilitatorberfungsi untuk mendengar dan memahami aspirasi para peternak, mampu memberikan dukungan, serta memberikan fasilitas kepada masyarakat melalui para penyuluh yang mereka utus untuk memberikan penyuluhan pemeliharaan ayam broiler di Desa Tanrara. Melalui penyuluhan ini, para peternak ayam broiler di Desa Tanrara dapat memberikan keluhan 
mereka mengenai kendala yang mereka dapatkan dalam memelihara ayam broiler seperti pemilihan bibit yang berkualita hingga penanganan penyakit unggas.

Selain memfasilitasi pemilihan bibit dan pencegahan penyakit pada ayam broiler, Dinas Perikanan, Kelautan, dan Peternakan Kabupaten Gowa melalui para penyuluhnya juga membantu para peternak di Desa Tanrara dalam mengembangkan pemasaran hasil ternak mereka. Melalui kegiatan penyuluhan, Dinas Perikanan, Kelautan, dan Peternakan Kabupaten Gowa memfasilitasi para peternak ayam broiler di Desa Tanrara dalam berakses ke pasar sehingga pemasaran ayam broiler mereka berkembang.

\section{Membantu Meningkatkan Sumber Daya dan Produktivitas Peternak}

Perkembangan sumber daya manusia khususnya dalam peternakan ayam broiler sangat diperlukan untuk perkembangan peternakan ayam broiler yang semakin hari permintaannya semakin meningkat. Potensi ini perlu diperhatikan untuk lebih meningkatkan produktivitas peternak ayam broiler yang ada di Desa Tanrara. Oleh karena, kegiatan penyuluhan sangat diperlukan oleh peternak ayam broiler untuk meningkatkan sumber daya mereka serta meningkatkan produktivitas mereka.sebagaimana yang diungkapkan oleh salah satu peternak ayam broiler di Desa tersebut:

"Sebelum mendapatkan penyuluhan, saya belum bisa memilih bibit ayam yang bagus, akibatnya hasil panen ayam saya kurang bagus. Meskipun sudah diberi pakan yang bagus, pertumbuhan mereka tidak maksimal. Hal ini membuat saya tidak berani untuk menambah bibit anakan ayam karena saya tidak mau merugi terlalu banyak. Namun, bapakbapak dari dinas peternakan saat memberikan pendampingan membantu saya dalam memilih bibit DOC yang baik serta caramemberikan vitamin sehingga pertumbuhan lebih subur. Setelah itu produksi ayam saya meningkat 30

\section{persen... "(Wawancara, MTS)}

Kualitas sumber daya yang baik dapat meningkatkan produktivitas para peternak dalam beternak ayam broiler.Hal ini dapat dicapai salah satunya didapatkan melalui kegiatan penyuluhan peternakan oleh Dinas Perikanan, Kelautan, dan Peternakan Kabupaten Gowa.Hasil yang didapatkan dari meningkatnya sumber daya ini adalah pemahaman masyarakat mengenai pemeliharaan ayam broiler yang baik sehingga produktivitas hasil panen mereka pun semakin meningkat.

\section{Penyuluhan Pemeliharaan Ayam Broiler Dapat Meningkatkan Hasil Peternakan Ayam Broiler}

Ayam ras pedaging (broiler) merupakan salah satu sumber pangan hewani yang cukup strategis dalam komponen pemenuhan pangan nasional dan sangat digemari khususnya di Propinsi Sulsel. Permintaan terhadap ayam broiler terus meningkat sejalan dengan meningkatnya pendapatan masyarakat dan jumlah penduduk. Ketergantungan pada impor dikhawatirkan akan memperlemah usaha ternak di dalam negeri. Oleh karena itu perlu dilakukan upaya khusus untuk meningkatkan produksi ternak yang tentunya juga akan berdampak pada kesejahteraan para peternak ayam broiler.

Untuk mengantisipasi maka diperlukan suatu usaha pemanfaatan potensi ternak dengan cara memfasilitasi peternak ayam broiler sehingga pertumbuhan produksi ternak dapat terlaksana dengan baik. Salah satu langkah yang diambil oleh Dinas Perikanan, Kelautan, dan Peternakan Kabupaten Gowa dalam rangka meningkatkan kesejahteraan para peternak ayam broiler adalah dengan memberlakukan program penyuluhan pemeliharaan ayam broiler bagi peternak ayam broiler di Desa Tanrara Kecamatan Bontonompo Selatan Kabupaten Gowa. Penyuluhan peternakan yang dilaksanakan oleh Dinas Perikanan, Kelautan, dan 
Peternakan Kabupaten Gowa terbukti telah mampu meningkatkan penghasilan para peternak ayam broiler di desa tersebut. Halhal yang menyebabkan penyuluhan dapat meningkatkan penghasilan para peternak ayam broiler di desa tanrara adalah sebagai berikut:

\section{Penyuluhan Mendorong Meningkatnya Produksi Dan Produktivitas Peternakan Ayam Broiler.}

Ayam Pedaging (Broiler) adalah ayam ras yang mampu tumbuh cepat sehingga dapat menghasilkan daging dalam waktu relatif singkat (5-7 minggu). Hal ini tentunya dapat mendatangkan keuntungan yang berlimpah bagi para peternak ayam broiler jika usaha ini dijalankan dengan baik. Namun, para peternak ayam broiler di Desa Tanrara umumnya masih memiliki pemahaman yang kurang mengenai cara pemeliharaan yang baik seperti pemilihan bibit yang baik, pemberian pakar yang benar, pencegahan penyakit, serta perawatan kandang. Hal ini tentunya berdampak pada produksi ayam broiler mereka yang kurang maksimal. Maka melalui penyuluhan pemeliharaan ayam broiler oleh Dinas Perikanan, Kelautan, dan Peternakan Kabupaten Gowa, peternak ayam broiler di desa Tanrara Kecamatan Bontonompo Selatan mulai merasakan perbedaan yang cukup signifikan dari hasil ternak mereka.

Manfaat yang didapatkan oleh peternak ayam broiler melalui penyuluhan adalah produktivitas serta produksi ayam mereka. Peningkatan produksi ayam broiler ini tentunya berdampak baik bagi peningkatan kualitas hidup para peternak. Oleh karena itu kegiatan penyuluhan peternakan ayam broiler sangat berpengaruh bagi peningkatan produksi ayam broiler di kalangan para peternak ayam broiler di desa Tanrara.

\section{Penyuluhan Mendorong Ketersedian/ Pasokan Ayam Broiler Selalu Stabildi Pasaran}

Kendala yang paling sering dialami untuk mengoptimalkan pasokan ayam broiler adalahlaju permintaan ayam broiler lebih tinggi dari laju peningkatan produksinya. Hal ini mengancam kestabilan pasokan ayam broiler dipasaran. Kurangnya pasokan ayam broiler disebabkan oleh tidak maksimalnya hasil panen para peternak ayam broiler sehingga mereka mereka tidak mampu untuk memenuhi kebutuhan pasar. Untuk mengatasi hal tersebut, Dinas Perikanan, Kelautan, dan Peternakan Kabupaten Gowa mencangangkan program penyuluhan peternakan ayam broiler untuk membantu para peternak ayam broiler mengoptimalkan hasil ternak mereka. Sebagaimana yang dilaksakan di desa tanrara sebagaimana di ungkapkan oleh salah satu Petugas Penyuluh Pertanian Lapangan (PPL) dari Dinas Perikanan, Kelautan, dan Peternakan Kabupaten Gowa dari wawancara berikut:

"data terakhir yang saya dapat, pasokan ayam broiler di sepanjang tahun 2014 ini masih melimpah di pasaran. Produksi ayam broiler semakin meningkat semenjak peternak di desa ini diberikan penyuluhan. Hal ini membuat mereka tetap mampu menjaga pasokan ayam broiler di pasar tetap ada karena kebutuhan ayam broiler di masyarakat semakin meningkat.." (WawancaraSS)

Pasokan ayam broiler dipasaran sangat melimpah karena produksi para peternak ayam broiler di desa Tanrara semakin meningkat setelah diberikan penyuluhan. Semakin meningkatnya jumlah produksi membuat para peternak mampu menyuplai permintaan ayam broiler dipasaran dapat terpenuhi bahkan melimpah di tahun ini. Pemeliharaan yang benar, peternak ayam broiler di desa Tanrara dapat menigkatkan produksi ayam broiler mereka sehingga mereka dapat menyuplai pesanan ayam broiler yang semakin bertambah.

8. Penyuluhan Mendorong Meningkatnya Pendapatan Dan Kesejahteraan Peternak Ayam Broiler diDesa Tanrara 
Fakta membuktikan dari tahun ke tahun kebutuhan masyarakat terhadap daging broiler terus meningkat. Seiring dengan meningkatnya minat masyarakat untuk mengkonsumsi daging broiler, terjadi juga peningkatan terhadap usaha peternakan ayam broiler. Hal ini sebagaimana diungkapkan oleh salah satu peternak ayam broiler dari wawancara berikut:

"sebelum mendapatkan penyuluhan, pendapatan yang saya dapatkan masih minim karena saya belum mengetahui proses pemeliharaan ayam broiler yang baik. Kira-kira penghasilan yang saya dapatkan sekitar 7 juta sekali panen. Tapi setelah mendapatkan penyuluhan, pendapatan yang saya dapatkan cukup meningkat yaitu meningkat menjadi 50 persen sekali panen" (Wawancara, RMB).

Melalui penyuluhan, peternak ayam broiler di Desa Tanrara dapat melakukan pemeliharaan yang benar sehingga produksi ayam broiler mereka pun meningkat. Hal ini tentunya membuat pendapatan mereka semakin meningkat hingga berkali lipat dibandingkan sebelum mereka mendapatkan penyuluhan hasil panen mereka masih minim. Dengan meningkatnya pendapatan para petrnak di desa tersebut, maka kesejahteraan para peternak pun dapat dicapai melalui pemeliharaan ayam broiler.

\section{Penyuluhan Mendorong Pemasaran Ayam Broiler Yang Semakin Meluas}

Kendala utama dalam budidaya ternak ayam potong ada pada sistem pemasaran dikarenakan hewan ternak ini tumbuh begitu pesat. Umur 30 hari berat badan seekor ayam broiler dapat mencapai 1 Kg lebih (siap dipasarkan). Sehingga apabila pemasarannya tidak memiliki sistem yang pasti atau tanpa pelanggan tentu saja para peternak akan kerepotan untuk menjual ayam tersebut sekaligus dalam sehari. Biaya paling besar dalam budidaya broiler terletak pada biaya pakan, jika sehari saja peternak terlambat dalam pemasaran maka mereka harus mengeluarkan biaya pakan yang cukup besar. Oleh karena itu, penyuluh dari Dinas Perikanan, Kelautan, dan Peternakan Kabupaten Gowa dapat berfungsi sebagai mediator bagi peternak ayam broiler untuk memperluas pemasarannya.

Awalnya para peternak ayam broiler di Desa Tanrara hanya memasarkan hasil ternaknya kepada para pengepul atau distributor (sistem satu jalur) langganan mereka yang berada di sekitar wilayah Bontonompo saja. Hal ini tentunya membuat produksi ayam broiler mereka tidak maksimal karena terbatasnya area pemasaran mereka. Melalui penyuluhan, Petugas Penyuluh Pertanian Lapangan (PPL) dari Dinas Perikanan, Kelautan, dan Peternakan Kabupaten Gowa sebagai fasilitator membantu para peternak ayam broiler di desa Tanrara untuk memperluas koneksi mereka hingga mencakup kecamatan lain di wilayah Gowa hingga bahkan pemasarannya sampai ke Makassar. Dengan meluasnya pemasaran ini, tentunya pendapatan peternak ayam broiler di desa tersebut semakin bertambah.

\section{K. PENUTUP}

Sebagai produk peternakan yang selalu dibutuhkan masyarakat, peternakan ayam broiler memiliki potensi yang cukup besar sebagai salah satu komoditi yang dapat dikembangkan oleh masyarakat Gowa khususnya peternak ayam broiler di Desa Tanrara. Oleh karena itu peran pemerintah dalam hal ini Dinas Perikanan, Kelautan, dan Peternakan Kabupaten Gowa melakukan penyuluhan pemeliharaan ayam broiler di Desa Tanrara Kecamatan Bontonompo Selatan Kabupaten Gowa. Adapun peran penyuluhan tersebut diantaranya memberikan pendidikan kepada peternak (educational roles), memberikan pendampingan/bimbingan teknis kepada peternak, sebagai fasilitator bagi para peternak, serta membantu 
meningkatkan sumber daya dan produktivitas peternak sehingga produksi dan produktivitas peternak ayam broiler di desa tersebut semakin meningkat.

Manfaat langsung yang didapatkan para peternak ayam broiler di Desa Tanrara dari penyuluhan pemeliharaan ayam broiler oleh Dinas Perikanan, Kelautan, dan Peternakan Kabupaten Gowa adalah meningkatnya hasil peternakan ayam broiler. Hal ini dikarenakan penyuluhan mampu mendorong meningkatnya produksi dan produktivitas peternakan ayam broiler, mendorong ketersedian/pasokan ayam broiler selalu stabil di pasaran, mendorong meningkatnya pendapatan dan kesejahteraan peternak ayam broiler di desa tanrara, serta membantu pemasaran ayam broiler agar semakin meluas sehingga hasil peternakan ayam broiler menjadi maksimal.

\section{DAFTAR PUSTAKA}

Ahmad, M. 2010. Analisis Efisiensi Penggunaan FaktorFaktor Produksi Pada Usaha Ternak Ayam Ras Pedaging di Kabupaten Magelang. Fakultas Ekonomi Universitas Diponegoro, Semarang.

Ali, F. 2012. Peran Penyuluh Pertanian Dalam Pengembangan Kelompik Tani. http://serbatani.blogspot.com/2012/01 /skripsi-peran-penyuluh-pertaniandalam.html (diakses tanggal 28 Januari 2012).

Anonim. Pedoman Pembangunan Pabrik Skala Kecil dan Proses Pengolahan Pakan. 2010. Jakarta: Direktorat Jenderal Peternakan

Anonim. Panduan Penulisan Skripsi. 2008. Universitas Budi Luhur: Fakultas Sosial dan Ilmu Politik.

Atmadilaga D. 2008. Masalah dan Masa Depan Industri Perunggasan Indonesia.Majalah Pertanian dan Telur Volume. 48. Yogyakarta.

Bungin, M. B. 2008. Penelitian Kualitatif: Komunikasi, Ekonomi, Kebijakan Public, dan Ilmu Sosial Lainnya. Jakarta: Putra
Grafika.

Departemen Pertanian. 2009. Analisis Konsumsi Pangan. Pusat Data dan Informasi Pertanian: Departemen Pertanian RI.

Hakim, L. 2010. Pemberdayaan Masyarakat: Sketsa Teori dan Pendekatan. Lembaga Perpustakaan dan Penerbitan Universitas Muhammadiyah Makassar.

Indonesian Commercial Newsletter (ICN). 2009. Laporan Market Intelligence: Perkembangan Peternakan Unggas di indonesia.

http://www.datacon.co.id/Ternak12009.html. (diakses tanggal 28 Januari 2012).

Martanegara, A. B. D. 1993. Hubungan Antara Keefektifan Metode Penyuluhan Dan Karakteristik Serta Sikap Peternak Terhadap Cara Pemberian Pakan Pada Sapi Perah. Laporan Penelitian. Fakultas Peternakan Unpad. Bandung.

Miles dan Humberman.1992. Analisis Data Kualitatif. Jakarta: Universitas Indonesia Press.

Rikawati, 2011. Optimalisasi Penggunaan Faktor-Faktor Produksi Peternakan Ayam Ras Pedaging. Bogor: Jurusan Manajemen fakultas Ekomoni dan Manajemen IPB.

Sjamsul, 2005. Lokakarya Nasional Inovasi Teknologi Dalam Mendukung Usahaternak Unggas Berdayasaing. Direktorat Jenderal Peternakan Departemen Pertanian.

Undang-Undang Perlindungan Konsumen 1999 (Undang-Undang Nomor 8 Tahun 1999). 2012. Jakarta: Sinar Grafika. 